原 著 三尖弁閉鎖不全の発生およびその進展にかかわる

三尖弁形態異常の心ェュー図法的検討

北海道大学医学部循環器内科 (指導 安田寿一教授)

三神 大世

\title{
ECHOCARDIOGRAPHIC STUDY ON MORPHOLOGICAL ABNORMALITIES \\ OF THE TRICUSPID VALVE IN RELATION TO THE DEVELOPMENT \\ OF TRICUSPID REGURGITATION
}

Taisei Mrkami, MD

Department of Cardiovascular Medicine, Hokkaido University School of Medicine

(Director: Prof. Hisakazu Yasuda)

\begin{abstract}
概要 本研究の目的は，臨床例における諸種の三尖弁形態変化と三尖升閉鎖不全との対応につ いて総合的に検討することである. 対象154例について，断層心エコ一図法を用いて三尖弁形態

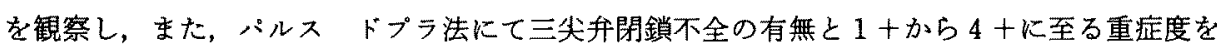
判定した. 先天性の弁形態異常は 9 例で，らちEbstein奇型や三尖弁異形成で 3 十以上の重症三 尖升閉鎖不全との関連が深かつた。残る145例については，三尖升輪の大ささ，并器質的変化， 弁輪線を基準とした収縮期の弁位置ならびに弁尖接合形態などを分析した。弁輪拡大の程度は 三尖升閉鎖不全の重症度と良く対応した。三尖升閉鎖不全の発生頻度は, 升器質的变化(15例), 弁尖の $6 \mathrm{~mm}$ 以上の前方偏位 (17例) および弁尖接合の欠如 (6 例) で $100 \%$ ，また，不整弁尖接 合 (12例) で $92 \%$ 之高頻度であつた。 3 十以上の重症三尖弁閉鎖不全の発生頻度は，ドーム形 成を伴 5 弁器質的変化 ( 4 例) と升尖接合の欠如で $100 \%$, 6mm以上の前方偏位で $88 \%$ と高かつ た. 一方, 弁後方偏位は, $3 \mathrm{~mm}$ 以上 (44例) ないし6 $\mathrm{mm}$ 以上（16例）のいずれで定義しても三 尖升閉鎖不全の有無, 重症度との関連が希薄であつた。これらは, 三尖弁閉鎖不全の発生と進 展の機序を解明する上で，また，臨床上，断層心エコ一図法にて三尖弁閉鎖不全を険索する上 で示唆に富む成績と考える。
\end{abstract}

\section{粕 言}

近年，三尖并閉鎖不全 (以下TR) の臨床的意義 が，とくにその手術療法の進歩に伴い，注目を集 めている1) 3!。しかし，TRとこれを惹起する三尖 弁形態異常との対応については不明の点が少なく ない。これは，複雑で変化し易い右心乐内の事象 を解明するための手段が従来乏しかつたためと考 えられる。心エコ一図法の最近の進歩は, パルス・ ドプラ法の血流計測の臨床応用 ${ }^{4) 61}$ 之断層法の解 像力向上をもたらした。これにょり，TRの重症度 診断と弁形態の詳細な観察を，両者は注济同時に

〔昭和59年10月17日受稿〕
生理的条件下で行なうことが可能となつた。 そこ でわれわれはこの心エコー図法を用いて，臨床 例に拈けるTRの有無, 重症度と諸種の三尖弁形 態変化との関連について検討した。

対象ならひに方法

\section{1. 对象}

対象は，1981年10月から1984年 3 月をで，心エ コー図法にてTRと三尖弁形態の観察を行ない良 好な記録の得られた154例である。年令は15才から 78才，男71例，女83例である，基礎疾患の内訳け を表 1 に示した。

\section{2. パルス ドブラ法}

装置はアロカ社製SSD 910 ドプラ診断装置を用 
表 1. 対象例の基礎疾患

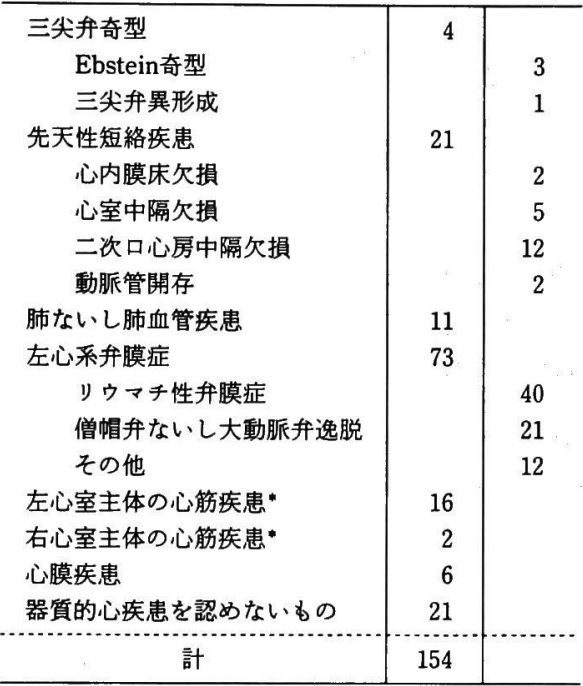

•心筋梗塞を含む

いた. 探触子の発振周波数は $3 \mathrm{MHz}$, 繰り返し周波 数は $4.4 \mathrm{KHz}$ ，サンプル ボリーームの大きさは ビーム方向 $1.5 \mathrm{~mm}$ ，ビームに垂直方向 $5 \mathrm{~mm}$ であ つた。本装置では実時間断層図上任意に定めたサ ンプル部位での血流速パターンを観察できる。左 半側臥位とした患者の左前胸壁上より得た三尖弁 水平断面上の右房内で，収縮期の半分以上にわた り持続する広帯域性のシグナルを検索した（図 1).このTRシグナルの得られた範囲を断層図上 に記録し，三尖弁尖からの最大到達距離を求め, Miyatakeらの基準6) に従いTR重症度を判定した (図 2).すなおちこれが $1.4 \mathrm{~cm}$ 以下のものをTR $1+, 1.5$ から $2.9 \mathrm{~cm} 2+, 3.0$ から $4.4 \mathrm{~cm} 3+$ および $4.5 \mathrm{~cm}$ 上上を $4+$ とした. TRシグナルを認 めなかつたものをTR (一)とした。なお， 3 十以 上のTRを重症TRと定義した。

\section{3. 断層心エコー図法}

パルス ドプラ法の直前ないし直後に断層心エ コー図法を施行した。装置はアロカ社製SSD 110 S, ATL社製Mark Vないしアロカ社製SSD 800S を使用した。前二者は機械走査式，後者は電子走 查式のセクタ一型探触子を有し，おのおのの発振 周波数は順に $3 \mathrm{MHz}, 3.5 \mathrm{MHz}, 2.5 \mathrm{MHz}$ であつ

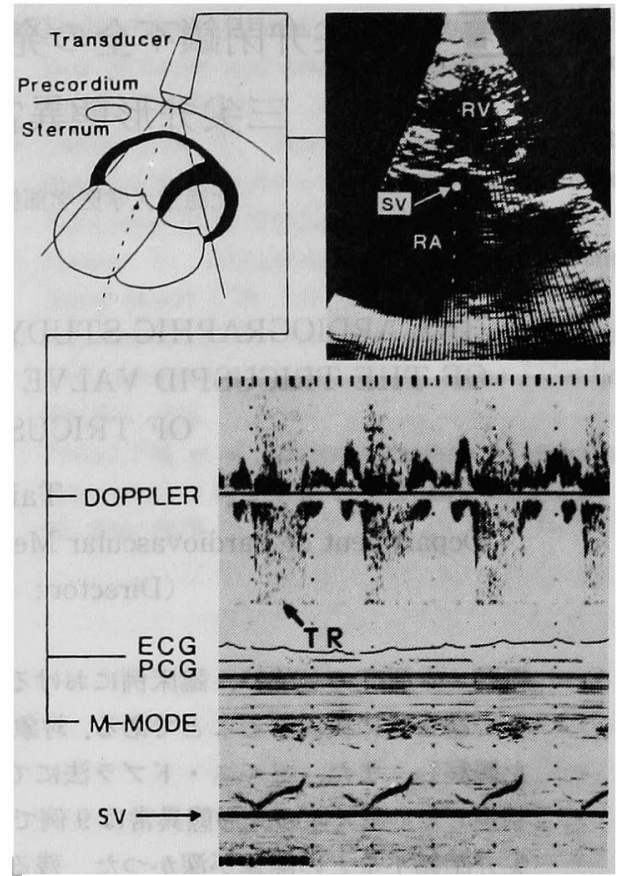

図 1.パルス・ドプラ法による三尖弁閉鎖不全の検出. 患者の前胸壁に置いた探触子より三尖弁水平断面を描 出し, その右房内にサンプル・ボリューム (SV) を設 定する (上段)。ドプラ記録上，三尖弁閉鎖不全 (TR) は収縮期の広带域性シグナルとして表示される（下 段). RA：右房, RV：右室.

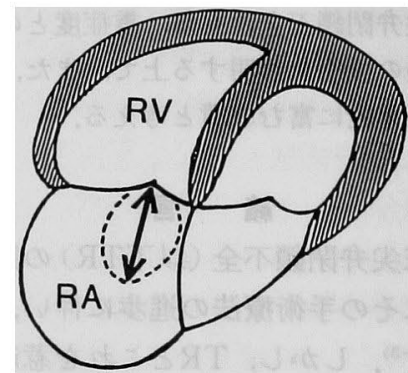

図 2.三尖弁閉鎖不全シグナルの最大到達距離の計 測. 水平断面上に三尖弁閉鎖不全シグナルの検出範囲 (点線)を記録し，このシグナルの三尖弁接合部からの 最大到達距離 (矢印)を計測する. RA：右房, RV： 右室.

た。実時間断層図はンニー社製VO 2711 ビデオカ セット・レコーダーを用い, $2 / 3$ インチ・ビデオテー プに記録し,これをソニー社製SVM 1110 ビデオ・ モーション アナライザーを用いて解析した。 
(1) 三尖弁輪の位置・形態異常をきたす先天性心 疾患（図 3,4）；水平, 矢状ならびに右室流入 路長軸断面を用い, Ebstein奇型，三尖弁異形成あ るいは中隔奇型に伴う弁輪位置異常の有無を検索 した。な拉，これらの異常を有する例では以下の 検討は行なわなかつた，(2)三尖弁輪面積（図 5)； 水平，矢状両断面を沶の扣の弁輪径が最大となる 方向で記録し，それぞれにつき弁可動部分のつけ 根間の距離を払張終期時相で計測した。 この両弁 輪径を長短径とする楕円が弁輪に一致するものと 仮定して弁輪面積を算出し，体表面積で補正して 用いた。 (3)弁器質的変化 (図 6)；水平, 矢状両 断面を用い, 石灭化ないし明瞭な肥厚の有無を検 索した。払張期ドーム形成の有無もあわせて検討

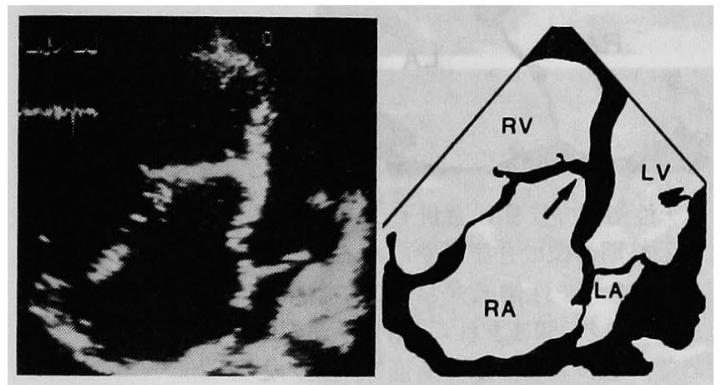

図 3. Ebstein奇型. 37才の女性で, 三尖弁閉鎖不全は $4+$ +例である. 水平断面（左）とその模式図（右） を示す．三尖弁中隔尖の基部が右室心尖部方向に大き く偏位している (知印). LA：左房, LV：左室, $\mathrm{RA}$ ：右房, RV：右室.
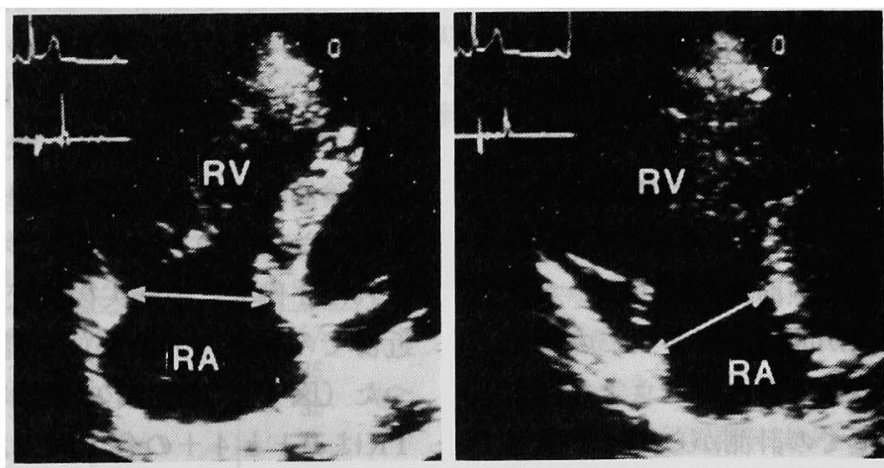

図 5.三尖弁輪の計測，水平断面（左）と矢状断面（右）のおのおのより桩張終期の 弁輪径を計測した，RA：右房, RV：右室.
した，(4)弁尖の前方偏位（図 7 B)； 水平断面を 用い，収縮後期において，弁尖先端の右室方向へ の偏位の程度を計測した。弁輪線より $3 \mathrm{~mm}$ 以上の 偏位を有意とし, $6 \mathrm{~mm}$ 以上のものを高度前方偏位 とした。（5)弁の後方偏位（図 7 C)；水平断面を 用い，収縮後期において，弁全体のうち最も強く
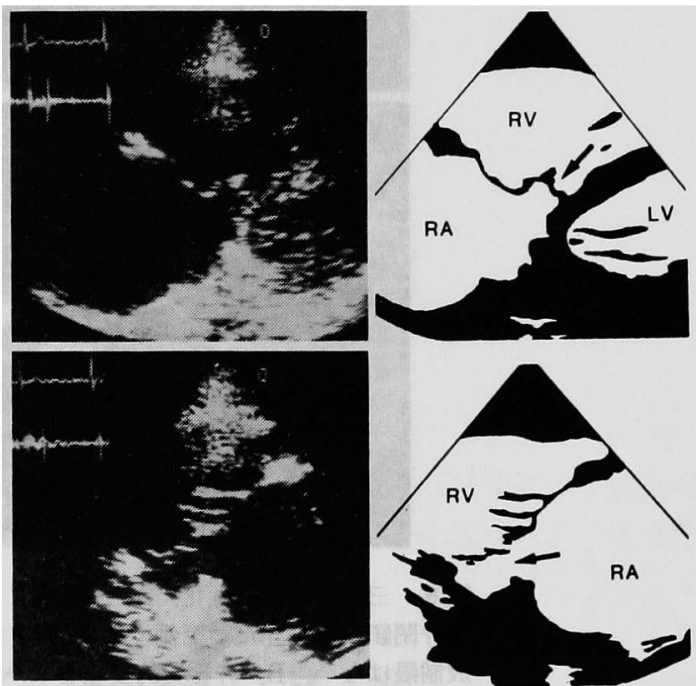

図 4. 三尖弁異形成．55才の女性で, 三尖弁閉鎖不全 かi 4 +の例である. 上段は水平断面（左）とその模式 図（右）で，三尖并中隔尖の基部が右室方向に軽く偏 位している (矢印). 下段は右室流入路長軸像 (左) と その模式図 (右) で, 中隔尖後尖交連部の弁欠損（矢 印)を認める, LV： 左室, RA：右房, RV：右 室. 


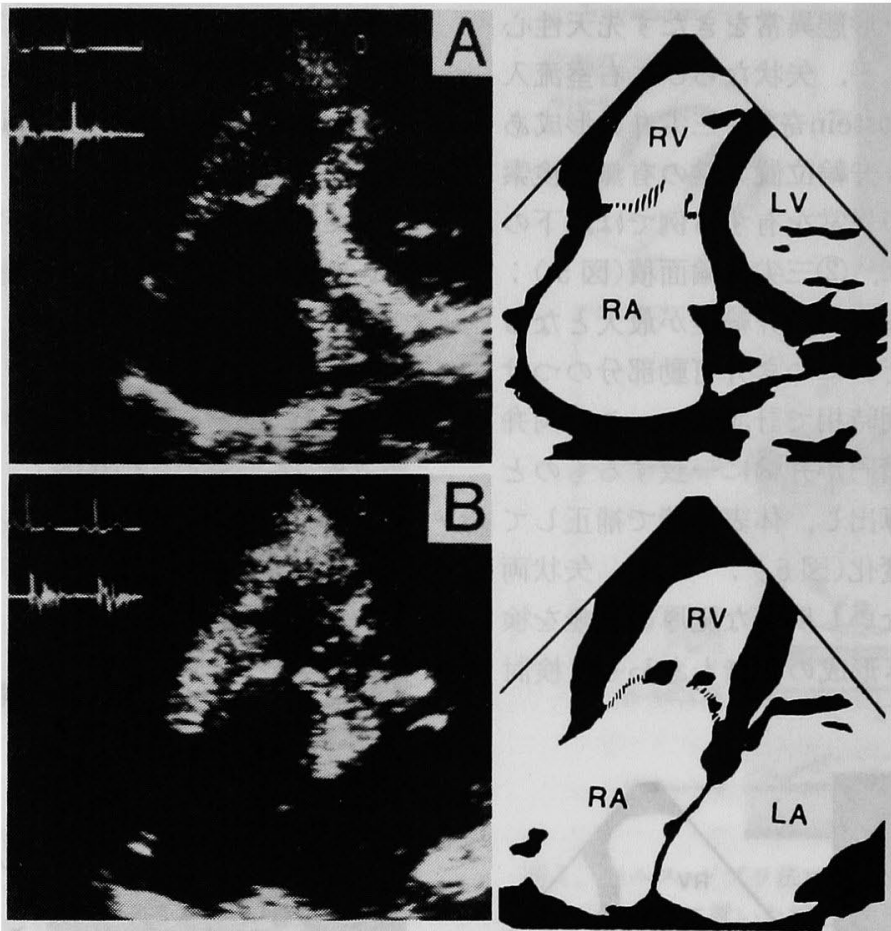

図 6. 三尖弁器質的变化. A. 弁肥厚：リウマチ性僧帽弁膜症に合併して $3+$ リ三 尖弁閉鎖不全をきたした例である(62才女性)．拡張終期の像で弁肥厚を認めるが，開 放制限はない. B. 并器質的変化とドーム形成：リウマチ性僧帽弁および大動脈弁 膜症に合併して $4+$ +の三尖弁閉鎖不全をきたした例である(50才女性). 払張早期の像 で, 弁の肥厚, 石灰化と同時にドーム形成を認める。おの捄の, 水平断面像（左）と その模式図(右)を示してある. LA：左房, LV：左室, RA：右房, RV：右 室.

右房方向へ偏位する部位でその程度を計測した。 弁輪線より $3 \mathrm{~mm}$ 以上の偏位を有意とし，6 $\mathrm{mm}$ 以 上のものを高度後方偏位とした，(6)不整弁尖接合 （図 $8 \mathrm{~A}, \mathrm{~B}$ ）；水平断面上，収縮後期の前尖中隔 尖接合部にずれを認めるもので, $3 \mathrm{~mm}$ 以上を有意 とした。（7)弁尖接合の欠如（図 $8 \mathrm{C}$ )；水平断面 上，収縮期を通じて両弁尖間に明瞭な離開のある むのとした。

上記のうち(4), (5), (6)の検討に際しては, 水平 断面の弁に対する入射角が問題となる。このため 本研究では, 同一のエューウゥンドウより得ら れた水平, 矢状両断面上での計測から, 水平断面 の三尖弁輪に対する入射角をあらかじめ求め，こ れが $60^{\circ}$ から $90^{\circ}$ 範囲にあるもののみを対象とし
た.

\section{成 績}

TRの重症度分類の結果を表 2 に示した。先天 性心疾患に基づく三尖弁輪の位置, 形態異常は全 154例中 9 例に認めた. 5 ちEbstein奇型が 3 例で, 中隔尖に30ないし $52 \mathrm{~mm}$, 後尖に 28 なし $48 \mathrm{~mm}$ の弁輪偏位があり，TRは 3 +が 1 例， 4 +が 2 例 であつた(図 3 )。 三尖弁異形成は後に手術で確認 された 1 例で, 中隔尖後尖交連部の弁欠損とその 近傍での軽度の弁輪偏位を認め, TRは 4 +であ つた（図 4)，心内膜欠損症によるものは 2 例で, TRは $1+$ と $4+$ 各 1 例であつた。心室中隔欠 損症の 5 例中 3 例に中隔尖基部の偏位を認め，5 ちTR (一) が 2 例, $2+$ +か 1 例であつた. 


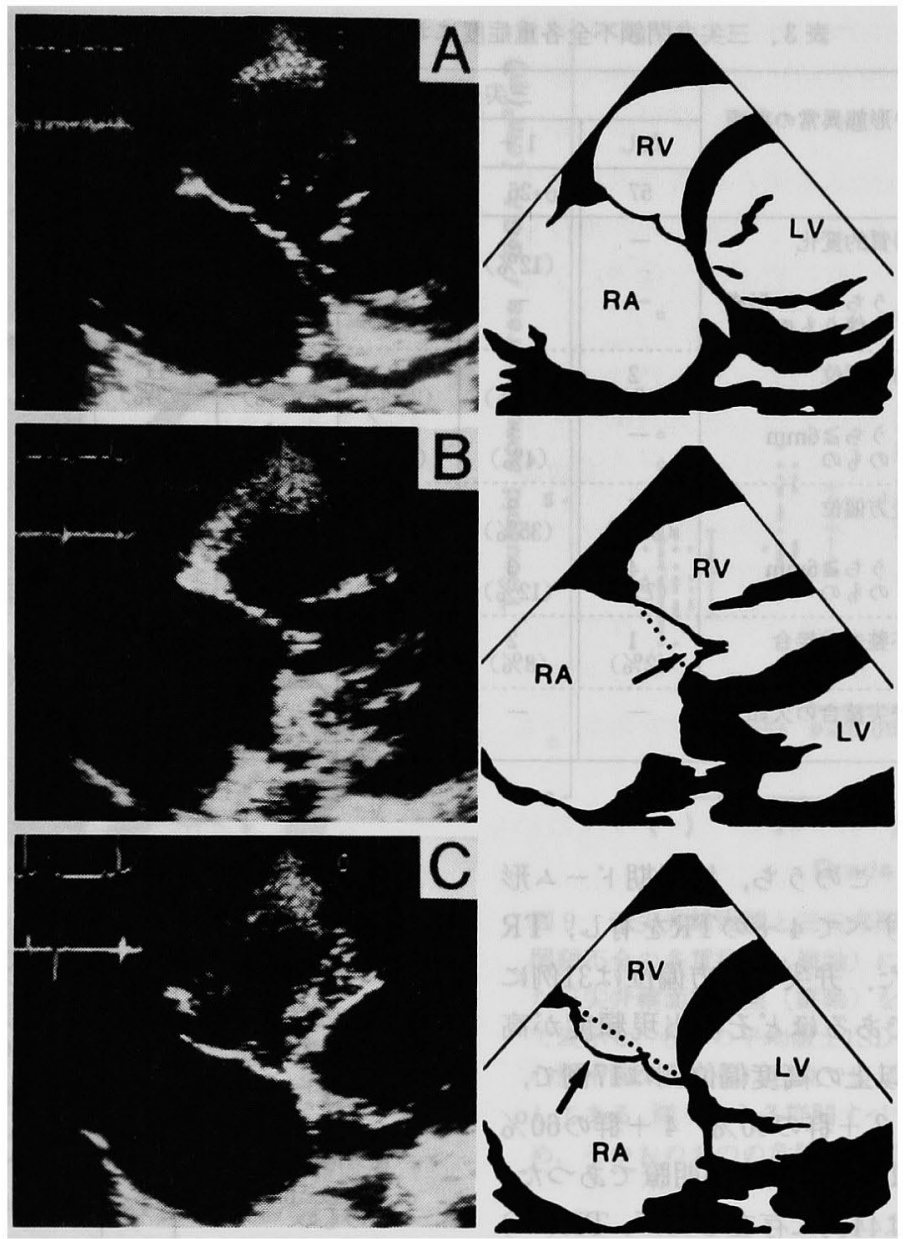

図 7 三尖弁の収縮期位置異常. A. 正常三尖弁位置：基礎疾患は大動脈弁閉鎖不 全で，三尖弁閉鎖不全はなかつた例である(18才男性)。両弁尖は正しく接合し，その 位置はほぼ弁輪線上にある. B. 弁尖の前方偏位：原発性肺高血圧症に合併して $3+$ 三尖弁閉鎖不全をきたした例である (40才女性). 両弁尖の先端が右室方向に偏 位している (矢印). C. 弁の後方偏位： 僧帽弁逸脱症とともに $1+$ の三尖弁閉鎖不 全をきたした例である(19才男性)，両弁尖とくに前尖の弁膜が右房方向に偏位してい る (矢印)。おのおの, 水平断面像 (左) とその模式図 (右) を示す. 図中の点線は弁 輪線を表わす. LA：左房, LV：左室, RA：右房, RV：右室.

表 2.三尖弁閉鎖不全の重症度

\begin{tabular}{c|c|c|c}
\hline $\begin{array}{c}\text { 三尖升閏鎖不全 } \\
\text { 金症全対象例 }\end{array}$ & $\begin{array}{c}\text { 三尖弁輪 } \\
\text { の奇型 }\end{array}$ & $\begin{array}{c}\text { それ以外 } \\
\text { のもの }\end{array}$ \\
\hline なし & 59 & 2 & 57 \\
$1+$ & 27 & 1 & 26 \\
$2+$ & 33 & 1 & 32 \\
$3+$ & 16 & 1 & 15 \\
$4+$ & 19 & 4 & 15 \\
\hline 計 & 154 & 9 & 145 \\
\hline
\end{tabular}

上記の 9 例を除き, 以下の検討の対象となつた のは145例であつた。.三尖弁輪面積とTR重症度と は，心房中隔欠損症の 12 例を除けば，良く対応し た(図 9). 体表面積で除した弁輪面積の值が 7 以 上であつた16例全例に重症TRを認めた。

TR各重症度群に打ける諸種の三尖弁形態異常 の出現頻度を表 3 亿示した。并器質的变化は15例 に認め, TR (-) 群にはなく, 重症TR群に比較 
表 3，三尖弁閉鎖不全各重症度における諸種弁形態異常の頻度

\begin{tabular}{|c|c|c|c|c|c|c|}
\hline \multirow{3}{*}{ 弁形態異常の種類 } & \multicolumn{5}{|c|}{ 三尖弁閉鎖不全の重症度 } & \multirow{2}{*}{ 計 } \\
\hline & なL & $1+$ & $2+$ & $3+$ & $4+$ & \\
\hline & 57 & 26 & 32 & 15 & 15 & 145 \\
\hline 器質的変化 & - & $\begin{array}{c}3 \\
(12 \%)\end{array}$ & $\left(\begin{array}{c}2 \\
(6)\end{array}\right)$ & $\begin{array}{c}5 \\
(33 \%)\end{array}$ & $\begin{array}{c}5 \\
(33 \%)\end{array}$ & 15 \\
\hline $\begin{array}{l}\text { 5ちドーム形成 } \\
\text { 老伴うむの }\end{array}$ & - & - & - & - & $\begin{array}{c}4 \\
(27 \%)\end{array}$ & 4 \\
\hline 前方偏位 & $\left(\begin{array}{c}2 \\
(4 \%)\end{array}\right.$ & $\left(\begin{array}{c}3 \\
(12 \%)\end{array}\right.$ & $\begin{array}{c}8 \\
(25 \%)\end{array}$ & $\begin{array}{c}7 \\
(47 \%)\end{array}$ & $\begin{array}{c}11 \\
(73 \%)\end{array}$ & 31 \\
\hline $\begin{array}{l}5 ち \geqq 6 \mathrm{~mm} \\
\text { のもの }\end{array}$ & - & $(4 \%)$ & $\begin{array}{c}1 \\
(3 \%)\end{array}$ & $\begin{array}{c}6 \\
(40 \%)\end{array}$ & $\begin{array}{c}9 \\
(60 \%)\end{array}$ & 17 \\
\hline 後方偏位 & $\begin{array}{c}16 \\
(28 \%)\end{array}$ & $\begin{array}{c}9 \\
(35 \%)\end{array}$ & $(31 \%)$ & $\begin{array}{c}7 \\
(47 \%)\end{array}$ & $(13 \stackrel{2}{\%})$ & 44 \\
\hline $\begin{array}{l}5 ち \geqq 6 \mathrm{~mm} \\
\text { の }\end{array}$ & $(7 \%)$ & $\begin{array}{c}3 \\
(12 \%)\end{array}$ & $\begin{array}{c}3 \\
(9 \%)\end{array}$ & $\begin{array}{c}6 \\
(40 \%)\end{array}$ & - & 16 \\
\hline 不整弁尖接合 & $\begin{array}{c}1 \\
(2 \%)\end{array}$ & $\begin{array}{c}2 \\
(8 \%)\end{array}$ & $\begin{array}{c}3 \\
(9 \%)\end{array}$ & $\begin{array}{c}3 \\
(20 \%)\end{array}$ & $\begin{array}{c}3 \\
(20 \%)\end{array}$ & 12 \\
\hline 弁尖接合の欠如 & - & - & - & $\begin{array}{c}1 \\
(7 \%)\end{array}$ & $\begin{array}{c}5 \\
(33 \%)\end{array}$ & 6 \\
\hline
\end{tabular}

的高頻度に存在した。このうち，桩張期ドーム形 成を合併した 4 例はすべて 4 +のTRを有し，TR 4 十群の $27 \%$ を占めた。并尖の前方偏位は31例に 存在し，TRが重症であるほどその出現頻度が高 かつた。 5ち，6mm以上の高度偏位例は17例で， TR(一)群にはなく, 3 +群の $40 \%, 4$ +群の $60 \%$ にこれを認め, 重症TRとの関連が明瞭であつた。 一方, 弁の後方偏位は44例に存在したが, TR (一) 群に $28 \%$ と高頻度にみられ，またTR重症度との 対応も明瞭でなかつた。 $6 \mathrm{~mm}$ 以上の高度偏位の 16 例に限つてもTR重症度との対応は不明瞭であつ た。不整弁尖接合は12例に存在し，TRの重症度が 増すとともに高頻度となる傾向を認めた。并尖接

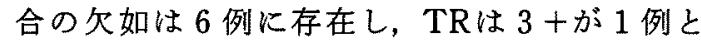
$4+$ 5 例であつた。

諸種の弁形態異常の存在下に扣けるTRおよび 重症TRの発生頻度を表 4 に示した. TRの発生頻 度は，弁後方偏位で $63 \%$ た高度後方偏位でも 75\%と低かつたが，他の弁形態異常ではいずれも 90\%以上の高頻度であつた。重症TRの発生頻度 は，ドーム形成を伴う升器質的变化と升尖接合の 欠如で $100 \%$ ，末た高度前方偏位で $88 \%$ と高かつ た。
表 4、諸粍の三尖升形態異常存在下での三尖弁閉鎖不 全の発生頻度

\begin{tabular}{|c|c|c|c|}
\hline 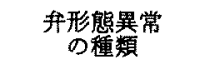 & 例数 & $\begin{array}{c}\text { 三怣弁閉鎖不全 } \\
\text { の発生頻度 }\end{array}$ & $\begin{array}{l}5 ち 3+\text { 以上 } \\
\text { bの発生頻度 }\end{array}$ \\
\hline 器質的要化 & 15 & $100 \%$ & $67 \%$ \\
\hline 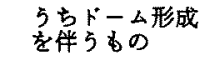 & 4 & $100 \%$ & $100 \%$ \\
\hline 前方偏位 & 31 & $94 \%$ & $58 \%$ \\
\hline $\begin{array}{l}5 ち \geqq 6 \mathrm{~mm} \\
\text { のちの }\end{array}$ & 17 & $100 \%$ & $88 \%$ \\
\hline 後方偏位 & 44 & $63 \%$ & $20 \%$ \\
\hline $\begin{array}{l}3 \hbar \geqq 6 \mathrm{~mm} \\
\text { のおの }\end{array}$ & 16 & $75 \%$ & $38 \%$ \\
\hline 不整升尖接合 & 12 & $92 \%$ & $50 \%$ \\
\hline 弁尖接合の欠如 & 6 & $100 \%$ & $100 \%$ \\
\hline
\end{tabular}

\section{考案}

種々の先天性心疾患, リウマチ性三尖弁膜症あ るいは三尖升逸脱症などにより，またしばしば機 能性に, TRの発生することが従来より知られて いる7!。しい，三尖弁の形態とTRの有無，重症 度の関係を総合的かつ詳細に検討した成績はまだ ない．本研究の目的は，この点に検討を加え，ど の様な三尖弁疾患ないし弁形態異常がTRとくに 重症TRを惹起するのかを解明することである。 


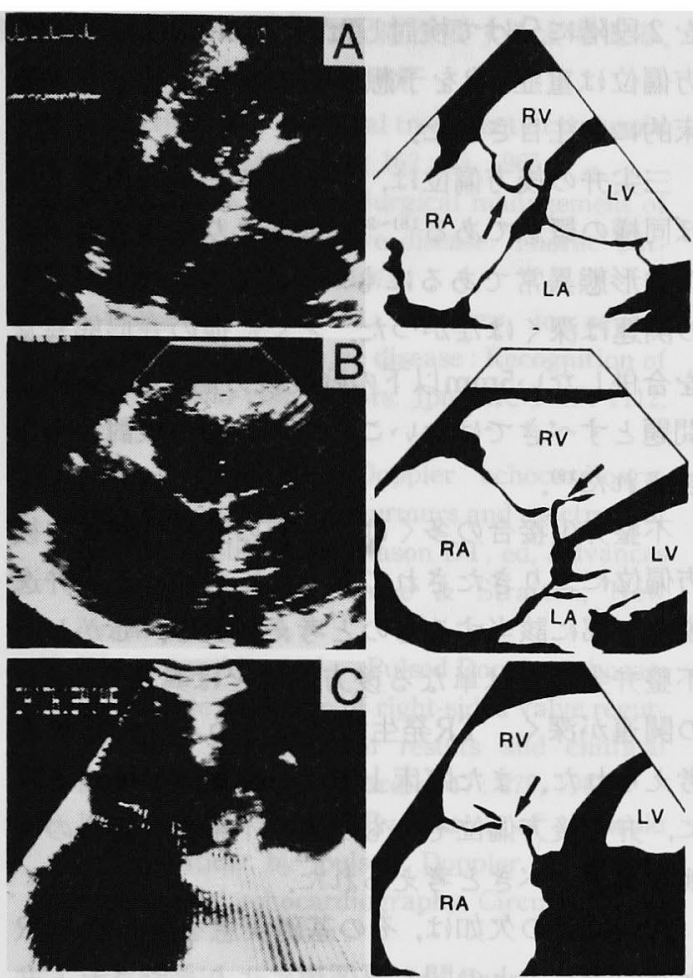

図 8.三尖弁の収縮期接合異常．A，不整弁尖接合： 大動脈弁閉鎖不全とともに $3+$ ○三尖弁閉鎖不全をき たした例である(18才，男性)．三尖弁前尖が弁先端近 くで大きく後方偏位し(矢印)，中隔尖との間にずれを きたしている．B．不整弁尖接合：原発性肺高血圧 症に合併した $4+$ ）三尖弁閉鎖不全の例である(33才， 女性). 三尖并中隔尖先端が前方偏位し (矢印), 前尖 との間にずれをきたしている．C．弁尖接合の欠如： 僧帽弁膜症に合併して 4 +の三尖弁閉鎖不全をきたし た例である(43才，男性)，収縮期を通じて両弁尖が接 合しない(矢印)。この例では著明な弁輪拡大と同時に 両弁尖の前方偏位も認める.おのおの, 水平断面像(左) とその模式図(右)を示してある. LA：左房, LV : 左室, RA：右房, RV：右室.

近年, 心ェコー図法は長足の進歩を成し遂げた. その第一はパルス・ドプラ法の心疾患への応用で ある。これにより，従来困難であつたTRの診断が 容易かつ非侵襲的に行ない得るようになつ た ${ }^{4) ~ 6)}$. 第二は断層法の分解能の向上で, 比較的検 出の難しかつた右心系構造物をも詳細に観察し得 るようになつた，時間的経過や検查時侵襲により 変化し得る右心系内の事象を解析するには, 現在

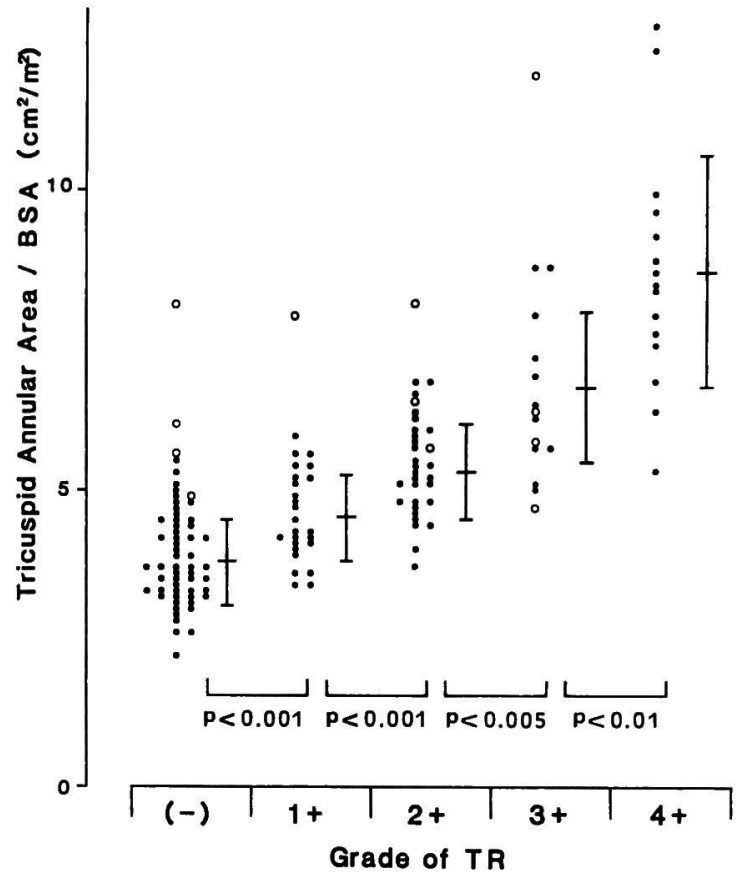

図 9.三尖弁輪面積と三尖弁閉鎖不全重症度.三尖弁 閉鎖不全の各重症度（横軸）における体表面積補正し た三尖弁輪面績の值（縦軸）を示す，個々の例を黒丸 で表示し, 各群の平均値士1SDをその右に示す。なお, 心房中隔欠損症例は白丸で表示し, 群平均からは除外 してある.隣り合ら各群間すべてに検定上有意差を認 め,そのおのおのの危険率を図中に示した。

の所，心エコー図法が最も優れた手段であると考 える.

パルス・ドプラ法によるTRの重症度評価法は Miyatakeらにより試みられ, 右室造影法との良い 対応が報告されている6). また，われわれは，本法 によるTR重症度と肝機能異常との対応から，本 法で 3 +以上のTRは臨床的意義が大であること を知り報告した8

三尖弁奇型のらちEbstein奇型で重症TRをきた し得ることは既に知られて扣り，本研究もこれを 支持した。一方，三尖弁異形成はまれな疾患とさ れ，その報告も少ない9．本対象例中の 1 例は本症 による弁の部分的欠損などのため重症TRをきた し，三尖弁形成術を施行するに至つた例である。 本例では術前に断層法にてその形態異常を把握す 
ることができた。われわれが示した本例の断層像 は，三尖弁異形成の臨床診断に貴重な示唆を与え るものと考える。なお，資料不足のため本研究から は除外したが，われわれは本例と同様の形態を有 した 1 例を他に䅅験し報告している10) 弁輪位置 異常中, 心内膜症欠損 ${ }^{11)}$ 中心室中隔久損 ${ }^{12)}$ による 例ではTRの有無, 重症度が多様であつた。

断層法に上る三尖升器質的变化の検討は三尖升 狭窄症との関連で報告されているものの ${ }^{13)}$ ，これ とTRとの対応についての研究は乏しい，本研究 では，リウマチ性弁変化を示唆する拡張期ドーム 形成と器質的变化の併存が重症TRに結びつくこ とを明らかにした，一方，単なる弁の肥厚中石灰 化も，TR発生に強く関連した。その成因は多様で あろらが、リウマチ性升变化の初期像をる含むも のと推察された。

TRと三尖弁輪払大との対応については既にい くつかの報告がなされている14117).われわれが先 に行なつた検討では，機能性TRの重症度と三尖 升輪払大との間に良い対応を認め, 弁輪払大が機 能性TRの発生や進展の重要な因子であることを 確認した ${ }^{16) 17)}$ 本研究では, 様々な原因による器質 的TRをる含めて検討したが，心房中隔欠損症例 を除くと，機能性の場合と同様の良い対応が得ら れた。この様な対象においても，TR進展の過程で 弁輪拡大が重要な役割を演ずるものと推察され た。な技，心房中隔欠損症例で他と異なる傾向が 得られたのは，升輪計測を拡張終期に行なつたた め, 右室機能の良い例では弁輪を過大評価し，TR が進展し右室機能も悪化したような例では正当に 評価したるのと理解される。

三尖弁尖の前方偏位は，右室の払大に伴う三尖 弁腱索の弁率引により引き起こされるものと考克 られる。この前方偏位が弁輪拡大とともに，充分 な弁接合を妨げ機能性TRの発生や進展をむたら す二大要因であることをわれわれは既に報告し $た^{16) 17}$. 本研究でも前方偏位の出現頻度とTR重症 度との間に明瞭な対応を認めた。弁尖の前方偏位 もまた，器質的TRを含めても，TR進展の重要な 要因の一つと考学られた。 また今回は偏位の程度
を 2 段階に分けて検討したが，6 $\mathrm{mm}$ 以上の高度前 方偏位は重症TRを予想させる断層所見として臨 床的にも注目された。

三尖弁の後方偏位は，いわゆる三尖弁逸脱とほ

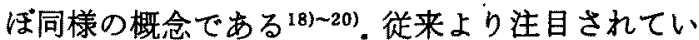
た弁形態異常であるにもかかわらず，そのTRと の関連は深くはなかつた。 とくに他の弁形態異常 を合併しない $5 \mathrm{~mm}$ 以下の軽度後方偏位は，臨床上 問題とすべきではないことが，今回の検討から示 唆された ${ }^{19)}$

不整弁尖接合の多くは，一方の弁尖先端部の後 方偏位によりきたされて扣り，いわゆる三尖弁逸 脱の一部に該当するすのと考えられる。しかし， 不整并尖接合は単なる後方偏位とは異なりTRと の関連が深く, TR発生機序の一つとして重要と 考光られた。束た臨床上三尖弁逸脱を診断する際 に，弁の後方偏位そのものより不整弁尖接合の有 無を重視すべきと考えられた。

弁尖接合の欠如は，その基礎疾患を問わず，TR と右心系搪大との間の悪循環によりきたされる弁 接合異常の極型と考えられる。本研究では，断層 法によるこの所見が例外なく重症TRを示唆する ことと同時にこれが重症TR例に決してまれな らず存在することを示し得た。

\section{結 論}

1）心エュー図法を用いて,諸種の三尖弁形態変 化とTRの有無，重症度との対応につき臨床例154 例に扣いて検討した。

2）重症TRをきたす弁形態異常として，三尖弁 そのものの重大な奇型, 三尖弁りウマチ性変化, 著明な弁輪払大，高度の弁尖前方偏位および弁尖 接合の欠如などが注目される。

3）TRの発生には, 非特異的な三尖弁器質的変 化，不整升尖接合执よび比較的軽度の弁輪拡大や 弁尖前方偏位も関連が深いと考える。

4）上記の成績は，TRの発生と進展の機序を解 明する上で，また，臨床的にTRを断層心エコー図 法で検索する際に示唆に富むるのと考える。

5）弁後方偏位はTRの有無や重症度との関連 が薄い，臨床上，三尖弁逸脱症の診断には過剩診 
断を避ける意味で慎重な配慮を要すると考える。

\section{文献}

1) Kay JH, et al : Surgical treatment of tricuspid insufficiency. Ann Surg 162: 53, 1965.

2) Carpentier A, et al : Surgical management of acquired tricuspid valve disease. Thorac Car. diovasc Surg 67: 53, 1974.

3) Takahashi $S$, et al: Surgery in severe rheumatic mitral valve disease : Recognition of severity and risk factors. Jpn Circ J $47: 1112$, 1983.

4) Johnson SL: Pulse-Doppler echocardiography : Localization of murmurs and spectrum of clinical applications. Mason DT, ed, Advances in Heart Disease, Grune \& Stratton, New York, 1977, p389.

5) Waggoner AD, et al : Pulsed Doppler echocardiographic detection of right-sided valve regurgitation: Experimental results and clinfical significance. Amer J Cardiol 47 : 279, 1981.

6) Miyatake $\mathrm{K}$, et al: Evaluation of tricuspid regurgitation by pulsed Doppler and twodimensional echocardiography. Circulation 66 : 777, 1982.

7) Braunwald E: Valvular heart disease. Braunwald E, ed, Heart Disease, WB Saunders, Philadelphia, 1980, p1149.

8）三神大世，他：超音波パルス ドブラー法による 三尖升閒鎖不全重症度診断々肝機能異常. J Cardiography $14: 353,1984$.

9) Becker $\mathrm{AE}$, et al: Pathologic spectrum of dysplasia of the tricuspid valve: Features in common with Ebstein's malformation. Arch Path 91 : 167, 1971.

10）间本洋, 他：右室後方に右房之交通寸る異常腔 を認め特異な心エコー図所見を呈した心房中隔欠
損の 1 例. J Cardiography $14: 423,1984$.

11) Somerville J: Atrioventricular defects. Mod Concepts Cardiovasc Dis $40: 33,1971$.

12) Esaghpour E, et al: Tricuspid insufficiency associated with aneurysm of the ventricular septum. Pediatrics 61 : 586, 1978.

13) Nanna $M$, et al: Value of two-dimensional echocardiography in detecting tricuspid stenosis. Circulation $67: 221,1983$.

14) Tei $C$, et al: The tricuspid valve annulus: Study of size and motion in normal subjects and in patients with tricuspid regurgitation. Circulation 66:665, 1982.

15) Ubago JL, et al: Analysis of tricuspid valve anular dilatation required to produce functional tricuspid regurgitation. Amer J Cardiol $52: 155,1983$.

16）三神大世，他：機能的三尖升閉鎖不全の発生と三 尖升・弁輪形態との関連：超音波バルス・ドブラー 法上断風心エコ一図法に上る検討。 J Cardiography $13: 215,1983$.

17) Mikami $T$, et al: Mechanisms for development of functional tricuspid regurgitation determined by pulsed Doppler and two-dimensional echocardiography. Amer J Cardiol 53 : $160,1984$.

18) Werner JA, et al : Occurrence and significance of echocardiographically demonstrated tricuspid valve prolapse. Amer Heart J $96: 180$, 1978.

19）加藤 洋, 他：健常者と心房中隔欠損の三尖弁動 態之三尖升輪径. J Cardiography $11 ： 209,1981$.

20) Brown AK, et al: Two-dimensional echocardiography and the tricuspid valve: Leaflet definition and prolapse. Brit Heart J 49:495, 1983. 